\title{
Bromide: A potential risk to livestock production in South Africa
}

\author{
N.H. Casey ${ }^{\#}$ H.L. Lucht \& B. Reijnders \\ Department of Animal and Wildlife Sciences, University of Pretoria, Hatfield, Pretoria 0002
}

(Received 22 November 2018; Accepted 21 November 2019; First published online 1 January 2020)

\begin{abstract}
Copyright resides with the authors in terms of the Creative Commons Attribution 4.0 South African Licence.
See: http://creativecommons.org/licenses/by/4.0/za

Condition of use: The user may copy, distribute, transmit and adapt the work, but must recognise the authors and the South African Journal of Animal Science.
\end{abstract}

\section{Abstract}

Keywords animals, groundwater, halides, toxicity, water quality

"Corresponding author: norman.casey@up.ac.za

\section{Introduction}

Groundwater is a vital resource for animal agriculture, wildlife and the local human populations over vast areas of South Africa. A constant supply of water is necessary to support the welfare of the population and to sustain economic activities. Drawing groundwater from aquifers occurs in all regions of the country and is not confined to the drier, low rainfall areas. The climate that prevails over the sub-continent is erratic and prone to alternating periods of adequate and sub-adequate rainfall. Intermittent seasonal dry periods and drought conditions require supplementation from groundwater resources where surface water is insufficient. In addition to erratic rainfall patterns, the topography favours rapid drainage off the central plateau and escarpment.

Historically, in areas where rainfall was erratic and rivers were non-perennial, farming practices were predominantly nomadic systems in which livestock moved to areas where water was available. The ability to access deep underground water sources with industrial drilling equipment made fixed farming systems possible because of the availability of a constant water source. This seemingly simple step changed the landscape of agriculture. On the one hand, it brought relief, but on the other, it led to consequences.

With time, noticeable differences in water properties and the quality of various groundwater sources allowed categorizing according to palatability and observed adverse effects that occurred in livestock and humans. This prompted in-depth investigation of water source compositions and subsequent development of water quality guidelines (WQG), which clustered water sources with similar properties and provided designations for use according to suitability, be it for irrigation, livestock watering, washing or as potable water for human consumption.

The variations in the quality of groundwater are well known and are recognised scientifically. Dissociated ions and conjugated forms of elements are collectively referred to as water quality constituents (WQC). The WQC determine water quality and its user specificity. These are published as WQG, which serve as classifications of water quality for defined purposes (Casey et al., 1996; Meyer et al., 1997; WRC, 2010; WHO, 2011). The Ministry of Environment, British Columbia (2015), noted that the principle of riskbased assessment is to represent safe levels of substances that protect different water uses. The approach is not to develop WQG that protect water quality per se or to provide direction on policy and decisions that affect it. Technological evolution has allowed for more sensitive testing of WQC and the capacity to identify more elements of interest to establish site-specific exposure risk. Direct comparisons between WQG reveal discrepancies in recommended 'safe values', which can be ascribed to observations from case studies with few imperative validations (Meyer \& Casey, 2012).

This article discusses the presence of bromide $\left(\mathrm{Br}^{-}\right)$in South African groundwater as a silent threat to livestock production.

Bromide occurs naturally in groundwater in combination with other ions such as chloride $\left(\mathrm{Cl}^{-}\right)$(Davis et al., 2004). This is a consequence of salt intrusion and local geographical situations in coastal regions (Agus 
et al., 2009), while for the inland areas it is a result of geological features and historical geographic conditions (Davis et al., 2004).

The dissociated anionic form of the diatomic halogen bromine $(\mathrm{Br})$ is $\mathrm{Br}^{-}$, which has chemical properties similar to other halides (fluoride $\left(\mathrm{F}^{-}\right)$, iodide $\left(\mathrm{I}^{-}\right)$and $\mathrm{Cl}^{-}$). It forms salts, which are mostly soluble in water with the exception of water insoluble salts, which are formed with copper $(\mathrm{Cu})$, mercury $(\mathrm{Hg})$, silver $(\mathrm{Ag})$, lead (Pb), platinum (Pt), and thallium (Th) (Jolles, 1966; NRC, 2005). Like $\mathrm{Cl}^{-}, \mathrm{Br}^{-}$will attach to mineral surfaces at low pH, and to organic solids (Davis et al., 2004).

In the presence of organic matter and oxygen, $\mathrm{Br}^{-}$forms organic compounds such as methyl bromide, which is a known endocrine-disrupting chemical. For the purpose of this article, the focus is on the interaction of inorganic $\mathrm{Br}^{-}$with $\mathrm{I}^{-}$and $\mathrm{Cl}^{-}$. Organic bromides are mentioned to draw attention to the probability of health risks when the many forms of $\mathrm{Br}^{-}$enter the production chain and, by extension, the food chain, although the topic is beyond the scope of this article.

The ocean is the greatest reservoir of $\mathrm{Br}^{-}$, with concentrations of approximately $67 \mathrm{mg} / \mathrm{L}$ (Heeb et al., 2014) and trace quantities are found in most groundwater (Davis et al., 2004). In the United States it was reported that $\mathrm{Br}^{-}$concentrations were highest in the coastal areas, decreasing further inland (Davis et al., 2004), which has implications for producing potable water for domestic use by desalinating sea water. In groundwater across South Africa naturally occurring $\mathrm{Br}^{-}$was reported to be present in concentrations that ranged from 0 to $132 \mathrm{mg} / \mathrm{L}$ according to collated data of the Water Research Commission (WRC) reports (Casey \& Meyer, 2001; Casey et al., 2001; Meyer, 2005; Casey \& Meyer, 2006; Korsten et al., 2016).

Water quality constituents do not occur in groundwater in isolation. Their presence in groundwater varies, depending on the geochemical properties of the bedrock surrounding the aquifers. Different aquifers can therefore have varying WQC composition, even when in close proximity.

Research on the WQC has focused on the constituents that are potentially harmful and lead to toxicity (Meyer \& Casey, 2012). Water is increasingly being recognized as a nutrient and a source of micro-minerals rather than merely a medium that promotes the uptake of nutrients from feed (Meyer \& Casey, 2004; Korsten et al., 2016). The dissociated state of WQC in solution allows them to interact and potentially have high bioavailability. Thus, groundwater of a specific composition has the potential to supplement trace elements that are deficient in feed. Conversely, WQC can react in such a way that they render essential trace elements biologically unavailable, resulting in deficiency. This is interesting because high bioavailability allows WQC access to biological systems in which they can exert a synergistic or an antagonistic effect. In practice, recommended safe levels of trace elements in water and livestock feed are seldom reported simultaneously (Meyer, 2015). The focus of this article is on the toxicity of WQC, because it is more complicated to mitigate toxic effects than to supplement deficient trace elements.

Groundwater that is pumped into open reservoirs and exposed to UV radiation is subject to speciation of $\mathrm{Br}^{-}$in the presence of oxygen to form bromate $\left(\mathrm{BrO}_{3}\right)$. This form of $\mathrm{Br}^{-}$is a known carcinogen (Jain et al., 1996; DeAngelo et al., 1998; Magazinovic et al., 2004; Bonacquisti, 2006; Moore \& Chen, 2006) and a potential by-product of water ozonation, which is used to produce pathogen-free potable water. Oxidative water treatment, as with ozonation, results in $\mathrm{Br}^{-}$oxidizing to hypobromous acid $(\mathrm{HOBr})$ and hypobromite $(\mathrm{OBr})$, which are the dominant $\mathrm{Br}$ species in chlorinated fresh water system. Hypobromous acid is the more reactive of the two forms, and readily reacts with many inorganic compounds (Heeb et al., 2014). It is essential to know the level of naturally occurring background $\mathrm{Br}^{-}$in a groundwater source that is specific to a site, because some water purification treatments may utilize chemicals that react with $\mathrm{Br}$ species to form carcinogens (Davis et al., 2004). This underlines the importance of a multifactorial approach to risk assessment instead of relying on a linear concentration-based model that is commonly used to establish WQG. The WQG are set at a concentration safety level for various elements, against which the actual WQC composition in a water sample can be compared to establish the fitness-for-use of that water source for livestock or domestic use.

The South African WQG for livestock watering (Casey et al., 1996) do not list $\mathrm{Br}^{-}$as a COC or potentially hazardous chemical constituent (PHCC). Similarly, there are no WQG in the British Columbia, Canada that reference $\mathrm{Br}$ (Ministry of Environment, British Columbia, 2015). In contrast, the Australian and New Zealand WQG for human consumption, which were updated in December 2013, set the maximum exposure level at $0.02 \mathrm{mg} / \mathrm{L}$ (National Health and Medical Research Council and the Natural Resource Management Ministerial Council, Australian Government, 2016). In the absence of established WQG for local conditions, international guidelines can be useful as a point of reference, but it would be ill advised to rely solely on these as a benchmark, because climate and production systems differ between countries. Additionally, the variations in aquifer composition necessitate a site-specific evaluation as the best strategy to determine fitness-for-use. Anthropogenic factors, such as pumping rate and seasonal use of boreholes, can influence aquifer WQC composition. 
Determining fitness-for-use of a groundwater source in the livestock context is important as it directs decision making regarding which groundwater sources are most suited to a specific livestock group. Livestock in various production phases differ in resilience to poorer quality groundwater. The toxicity of WQC depends on the intake rate and exposure time, the physiological state of the animal, and the interaction between WQC in the water.

The chemical form of a WQC determines its potential bioavailability in the animal after it has been ingested. Ions regulate cell membrane permeability, as with the principal electrolytes sodium $\left(\mathrm{Na}^{+}\right)$and $\mathrm{Cl}^{-}$in the extracellular fluid and potassium $\left(\mathrm{K}^{+}\right)$in the intracellular fluid and the heart (Hribar et al., 2002). In the gastrointestinal tract, $\mathrm{Br}^{-}$forms $\mathrm{HBr}$ in mucosal cells in the same manner as hydrochloric acid. It is readily absorbed via the passive chloride transport mechanism and transported to the liver, where it is not metabolized (Baird-Heinz et al., 2012), and to various other tissues and organs via the blood to move freely to multiple sites. In white blood cells, $\mathrm{Br}^{-}$and $\mathrm{Cl}^{-}$are oxidized with hydrogen peroxide and react with biomolecules of pathogens as part of the mammalian host defence system (Heeb et al., 2014). Plasma $\mathrm{Br}^{-}$ levels vary linearly with their concentration in the diet (NRC, 2005).

The distribution of $\mathrm{Br}^{-}$throughout the body is similar to that of $\mathrm{Cl}^{-}$, which relates to $\mathrm{Br}^{-}$being competitive with $\mathrm{Cl}^{-}$(Pavelka et al., 2000b). The half-life of whole-body $\mathrm{Br}^{-}$at normal dietary $\mathrm{Cl}^{-}$levels is 10 to 12 days in humans, 3 to 8 days in rats and 15 days in dogs. Although many authors have stated that the half-life depends on the $\mathrm{Cl}^{-}$level in the body, and that depressed $\mathrm{Cl}^{-}$levels dramatically increase the half-life of $\mathrm{Br}^{-}$(Pavelka et al., 2000b; Frances et al., 2003; Babicky et al., 2005; NRC, 2005), Pavelka et al. (2005) showed that the biological half-life of $\mathrm{Br}^{-}$is dependent on the intake of $\mathrm{Na}^{+}$rather than $\mathrm{Cl}^{-}$. It is also dependent on the physiological state of the animal: rat dams have the lowest $\mathrm{Br}^{-}$half-life, just 44 hours, compared with their non-weaned offspring at 269 hours (Babicky et al., 2005). The short half-life of $\mathrm{Br}^{-}$in the lactating female is probably because $\mathrm{Br}$ is excreted in the milk, and in the urine and faeces. Half-life also depends on the organ in which $\mathrm{Br}^{-}$accumulates. According to Pavelka et al. (2000a), the liver has the longest half-life of $\mathrm{Br}^{-}$at 235 hours, with the thyroid gland and brain having the shortest half-life at 94 hours. Whole-body half-life was 198 hours, which was longer than that of most of the tissues that were studied (Pavelka et al., 2000a). These authors reported significant correlation between values of steady state concentration of $\mathrm{Br}^{-}$and the biological half-life in tissues, the liver being an exception.

There is competition between $\mathrm{Br}^{-}$and $\mathrm{Cl}^{-}$in all organs - with the exception of the thyroid - where $\mathrm{Br}^{-}$ competes with $\mathrm{I}^{-}$. In the thyroid, $\mathrm{Br}^{-}$is preferentially taken up to replace $\mathrm{I}^{-}$, thus disrupting the production of thyroid hormones $\mathrm{T}_{3}$ and $\mathrm{T}_{4}$ over longer periods of exposure in broilers (Du Toit \& Casey, 2012). Compensatory action by the thyroid may induce hypothyroidism and $\mathrm{Br}^{-}$toxicity, which are expressed as secondary $\mathrm{I}^{-}$deficiency. High exposure to $\mathrm{Br}^{-}$is associated with damaged thyrocytes (Meyer, 2015), and lower feed and water intakes, adversely affecting production (Du Toit \& Casey, 2010).

The body does not distinguish between $\mathrm{Br}^{-}$and $\mathrm{Cl}^{-}$, and excess $\mathrm{Br}^{-}$replaces $\mathrm{Cl}^{-}$in the total halide pool owing to its pharmacokinetic properties. The blood-brain barrier is permeable to $\mathrm{Br}^{-}$, in which $\mathrm{Br}^{-}$uptake exerts a sedative effect in the central nervous system. Similarly, the placental barrier is permeable to $\mathrm{Br}^{-}$and trans-placental movement exposes the foetus to $\mathrm{Br}^{-}$during critical stages of development. The toxicity effects in the foetus are dependent on the quantity and exposure time of $\mathrm{Br}^{-}$that is ingested by the dam, resulting in impaired growth, negative impact on differential development, and the possibility of congenital goitre and hypothyroidism as a result of secondary $\mathrm{I}^{-}$deficiency. The excretion of $\mathrm{Br}^{-}$into the milk further compromises the viability of mammalian neonates. In female rats, a high concentration of $\mathrm{Br}^{-}$reduced $\mathrm{I}^{-}$accumulation in the mammary glands, increased renal excretion, and the pups exhibited thyroid abnormalities and reduced weight gain (Pavelka et al., 2002; Pavelka, 2004).

The primary excretion route is renal at approximately $5 \%$ of the ingested rate per 24 hours (Pavelka et al., 2000b), while excretion also occurs via faeces, saliva and sweat. Preliminary results showed that despite high $\mathrm{Br}^{-}$ingestion, the urinary excretion rate in Merino sheep is constant (Casey et al., 2017). The phenomenon of $\mathrm{Br}^{-}$being competitive with $\mathrm{Cl}^{-}$and probably infiltrating the $\mathrm{Cl}^{-}$'space (Pavelka et al., 2000a), the relatively low urinary excretion rate (5\%) found in rats (Pavelka et al., 2000b) and the recycling of body water in ruminants, may exacerbate the likelihood of $\mathrm{Br}^{-}$accumulation in the body from groundwater that contains low concentrations that are ingested over extended periods. This has implications for the safety of animal products that enter the food chain if $\mathrm{Br}^{-}$that is retained in the tissues, milk and eggs is at concentrations above the NOAEL set in the South African WQG. In the body, $\mathrm{Br}^{-}$is preferentially absorbed when competing with $\mathrm{Cl}^{-}$, which is evident in the kidney, where reabsorbed $\mathrm{Br}^{-}$triggers preferential excretion of $\mathrm{Cl}^{-}$.

Decreased fertility in male and female animals are expressions of endocrine-disrupting effects. In male rats, observed disturbances of endocrine function of the thyroid, testes and adrenal glands resulted in hypothyroidism and reduced spermatogenesis following exposure to high concentrations of $\mathrm{Br}^{-}$(Loeber et al., 1983). 
Risk assessment because of WQC is complex and requires observations of a number of parameters. A proposed model that is based on the intakes, physiology, and environmental factors illustrates the parameters that could be included in an assessment (Casey et al., 1998a,b; Meyer, 1998; Meyer \& Casey, 2012):

$\int($ risk $)=X 1$ [Animal (or person) type] * X2[Animal (or person)'s physiological status] * $X 3$ [environmental demands] * X4[water (PHCC) intake and turnover rate] * X5[level of PHCC] * X6[physiological effect of $\mathrm{PHCC}]^{*} \ldots . . \mathrm{Xn}$ * $\mathrm{e}$

This is essentially a metric system to estimate more accurately the probability of a WQC becoming a $\mathrm{COC}$ or PHCC. Text box 1 illustrates a practical approach to risk assessment.

Text box 1 Guide to water quality constituents risk assessment

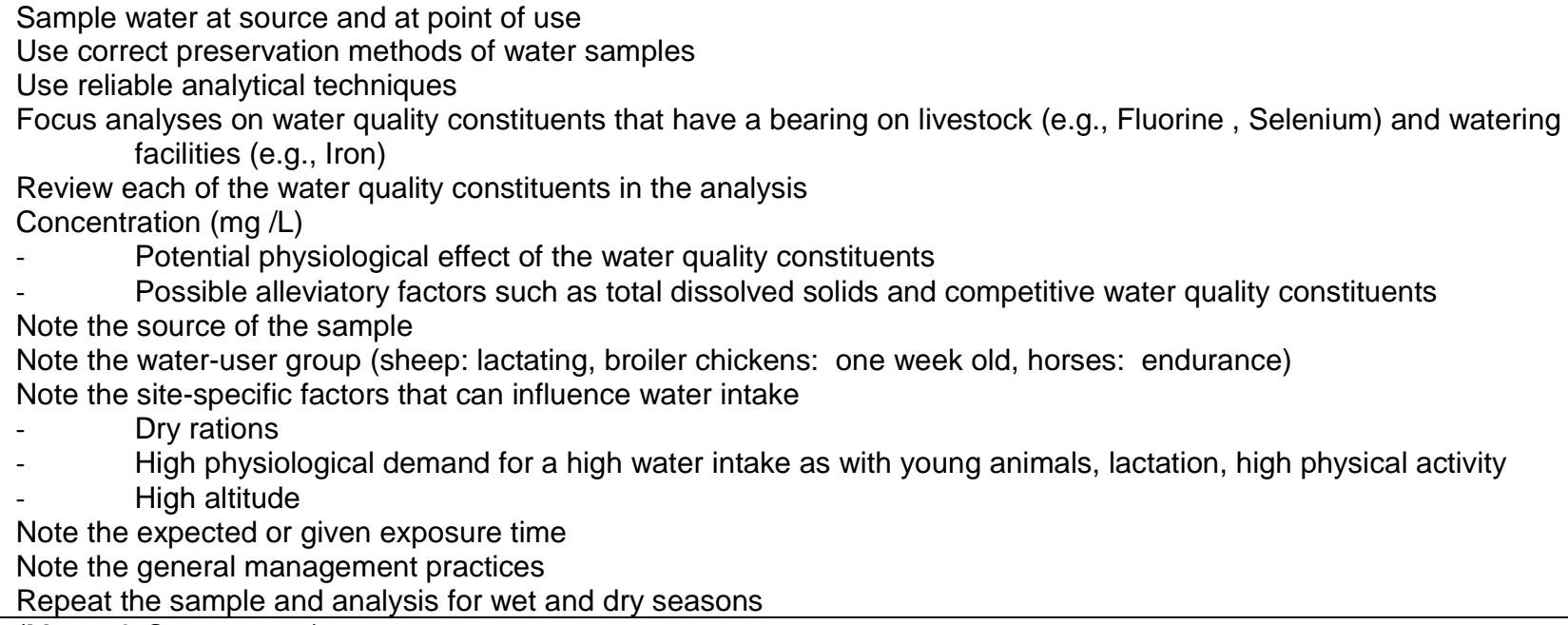

Casey and Meyer's (2001) report lists $\mathrm{Br}^{-}$as having a target water quality range of $0-3 \mathrm{mg} / \mathrm{L}$. A subsequent report (Casey \& Meyer, 2006) introduced $0.01 \mathrm{mg} / \mathrm{L}$ as a WQG value to align it with similar limits. Although no conclusive evidence has supported the value, $0.01 \mathrm{mg} / \mathrm{L}$ was adopted as an acceptable norm and applied as a WQG value (Korsten et al., 2016). This relates to $0.01 \mathrm{mg} / \mathrm{L}$ as the default level that is recommended by Regulation (EC) No 396/2005 on many residues in which the maximum residue level (MRL) has not been validated (European Parliament, 2005).

Subsequently, Lucht et al. (2018), having tested concentrations of $\mathrm{Br}^{-}$that was injected into fertilized chicken (Gallus gallus domesticus) eggs, reported that $\mathrm{Br}^{-}$is toxic to embryos at $1 \mathrm{mg} / \mathrm{L}$ and lethal at concentrations that are greater than $1 \mathrm{mg} / \mathrm{L}$. Embryo survival was significantly negatively correlated $\left(R^{2}=-\right.$ 0.92) with increasing $\mathrm{Br}^{-}$concentrations. Concentrations that were greater than $0.01 \mathrm{mg} / \mathrm{L}$ showed potentially severe effects on developing embryos. The NOAEL target water quality range in developing chicken embryos was $\leq 0.01 \mathrm{mg} / \mathrm{L}$.

This was the first conclusive validation of $\mathrm{COC}, \mathrm{PHCC}$ and NOAEL for $\mathrm{Br}^{-}$of $0.01 \mathrm{mg} / \mathrm{L}$ that appeared in literature. The chicken embryo, after direct injection of the substance to be tested into the albumen of the fertilised egg, is a highly sensitive assay for toxic effects of substances on a whole organism level over a short period, enabling identification of a stage at which embryonic death or other effects might occur (Korhonen et al., 1982). It also enables testing of direct effects on growing embryos independently of maternal influences that are present in mammalian animal models. The method has been used for this reason to study toxicological effects of various substances on target organ development and on the whole organism, especially in current nano-medical research (Sawosz et al., 2014). Although the chicken embryo model is highly sensitive, and could be regarded as a sentinel species test, the same conclusion may not apply to other types of livestock, which would require validation through controlled experiments.

The use of sentinel species for monitoring PHCC in the environment is not a new concept and is implemented mostly to monitor organic EDC in aquatic systems, as the aquatic animal models are highly sensitive to pollution. Areas were flagged as high risk when $\mathrm{Br}^{-}$concentrations were greater than0.01 mg/L. 
Site-specific observational recording of pathological conditions of livestock, which measure blood parameters and the analysis of harvested organs, have contributed significantly to associating the presence of WQC concentrations with these parameters. The effect of naturally occurring $\mathrm{Br}^{-}$in groundwater, and that resulting from contamination of anthropogenic origin such as disinfectants and pesticides, in these areas was tested using broiler chickens and free-roaming village chickens in the area as sentinel species (Meyer, 2015). Tissue and blood sampling of these birds indicated that birds that were exposed to elevated $\mathrm{Br}^{-}$ concentrations in drinking water presented with thyroid anomalies and dysfunction (Meyer, 2015).

Vulnerable populations include neonates, females in gestation and lactation, individuals in an active growth phase, and immunocompromised individuals. Each production phase presents specific physiological demands. Water intake is a key factor to consider when identifying vulnerable individuals. Actively growing weaned animals and lactating females have higher water intake to meet the physiological demands of muscle and milk production, respectively. The risks of toxicity for these groups are simple to identify because high intake of water with high concentrations of PHCC expose them to acute toxicity symptoms.

Low concentrations of WQC, in this case $\mathrm{Br}^{-}$, that are ingested over a longer period are the reason that it is considered a silent threat. When risk assessment is done in terms of metabolic body mass $\left(\mathrm{BW}^{0.75}\right)$ it is clear that foetuses, neonates and young animals are at greater risk of toxicity than older, larger animals because they are physically smaller and in a state of active growth and tissue accretion. Mammalian neonates have an additional factor that elevates the risk of toxicity, which is the excretion of $\mathrm{Br}^{-}$into the milk on which they are dependent until weaning.

Similarly, in the human context, vulnerable populations could mirror those found in livestock, with the exception of including older adults owing to the comparatively longer lifespan of humans. An additional factor that contributes to $\mathrm{Br}^{-}$toxicity risk in humans is the compounding effect of $\mathrm{Br}^{-}$in the drinking water that enters the food chain, where livestock ingest $\mathrm{Br}^{-}$through drinking water and transfer it into tissues, milk and eggs. People that reside in affected areas use the same groundwater source as their livestock for drinking and cooking meat and organs, in addition to the consumption of milk and eggs. The compounding effect of natural $\mathrm{Br}^{-}$paired with chronic exposure puts humans at risk of adverse toxicity effects on health.

\section{Conclusion}

Across South Africa, there are areas in which high concentrations of $\mathrm{Br}^{-}$are naturally present in groundwater. The prevalence of high-risk groundwater overlaps with areas where groundwater is the main water source for livestock watering and human consumption. Although concentrations of $\mathrm{Br}^{-}$in the groundwater may be low according to South African WQG for livestock watering, chronic exposure increases the risk of toxicity. Livestock may remain asymptomatic, since the production cycle is far shorter than the natural lifespan of the animals. However, risk to a vulnerable human population of concern because their longer lifespan results in a longer period of exposure. Regular seasonal sampling of groundwater is necessary to mitigate risk in areas that report problems in livestock production and human health. When sitespecific WQC composition of groundwater has been established, fitness-for-use is determined from comparisons between $\mathrm{Br}^{-}$and other element concentrations, and the NOAEL values in the South African WQG. This permits the allocation of poorer quality groundwater to more resilient livestock groups, reserving safer groundwater for use by vulnerable populations. When suitable alternative water sources are unavailable, the recommendation is to treat groundwater that is intended for human use, and, where necessary, for livestock watering.

\section{Acknowledgements}

The authors wish to acknowledge the Water Research Commission of South Africa, Private Bag X03, GEZINA, 0031, South Africa, for enabling the WRC research reports cited, and the National Research Foundation for funding through the incentive grant to NHC, reference: PR-IFR180205310035/UID96806. 


\section{Authors' Contributions}

The authors contributed equally to the content. NHC and HL prepared it for publication.

\section{Conflict of Interest Declaration}

There is no conflict of interest.

\section{References}

Agus, E., Voutvhkov, N. \& Sedlak, D.L., 2009. Disinfection by-products and their potential impact on the quality of water produced by desalination systems: A literature review. Desalination 237(1-3), 214-237.

Babicky, A., Pavelka, S. \& Vobecky, M., 2005. Biological half-lives of bromide and sodium in the rat are connected and dependent on the physiological state. Biol. Trace Elem. Res. 103, 49-58.

Baird-Heinz, H.E., Van Schoick, A.L., Pelsor, F.R., Ranivand, D.L. \& Hungerford, L.L., 2012. A systematic review of the safety of potassium bromide in dogs. J. Am. Vet. Med. Assoc. 240, 705-715.

Bonacquisti, T.P., 2006. A drinking water utility's perspective on bromide, bromate and ozonation. Toxicology 221, 145148.

Casey, N.H. \& Meyer J.A., 2001. An extension to and the further refinement of a water quality guideline index system for livestock watering: Volume 1: Rural communal livestock production systems and wildlife production systems. WRC Report No 857/1/01. Water Research Commission. Gezina, South Africa.

Casey, N.H. \& Meyer, J.A., 2006. The application of risk assessment modelling in ground water for humans and livestock in rural, communal systems. WRC Report No 1175/1/06. Water Research Commission. Gezina, South Africa.

Casey, N.H., Meyer, J.A. \& Coetzee, C.B., 1998a. An investigation into the quality of water for livestock production with the emphasis on subterranean water and the development of a water quality guideline index system: Volume 1. Development and modelling. WRC Report No K5/644/1/98. Water Research Commission. Gezina, South Africa.

Casey, N.H., Meyer, J.A. \& Coetzee, C.B., 1998b. An investigation into the quality of water for livestock production with the emphasis on subterranean water and the development of a water quality guideline index system: Volume 2. Research results. WRC Report No K5/644/1/98. Water Research Commission. Gezina, South Africa.

Casey, N.H., Meyer, J.A. \& Coetzee, C.B., 2001. An extension to and further refinement of a water quality guideline index system for livestock watering. Volume 2: Poultry production systems and water quality for ostrich production. WRC Report No 857/2/00. Water Research Commission. Gezina, South Africa.

Casey, N.H., Meyer, J.A. \& Kempster, P.L., 1996. South African water quality guidelines (second edition). Agricultural use. Volume 5: Livestock watering. Department of Water Affairs and Forestry, Pretoria, South Africa.

Casey, N.H, Reijners, B. \& Myburgh, J.B., 2017. Bromide intake via water and urinary excretion rates in a ruminant model. 68th Congress, European Association for Animal Production (EAAP), Tallinn, Estonia. Poster Session 43 no 17. Book of Abstracts, pp 394. http://www.eaap.org/Annual_Meeting/2017_tallin/eaap_boa_68th_2017.pdf

Davis, S.N., Fabryka-Martin, J.T. \& Wolfsberg, L.E., 2004. Variations of bromide in potable ground water in the United States. Ground Water 42(6-7), 902-909.

DeAngelo, A B., George, M.H., Kilburn, S., Moore, T.M. \& Wolf, D.C., 1998. Carcinogenicity of potassium bromate administered in the drinking water to male B6C3F1 mice and F344/N rats. Toxicol. Pathol.26, 587-594.

Du Toit, J. \& Casey, N.H., 2010. Effect of bromine and iodine in drinking water on production parameters of broilers. S. Afr. J. Anim. Sci. 40(4), 301-310.

Du Toit, J. \& Casey, N.H., 2012. Iodine as an alleviator of Br toxicity in the thyroid, liver and kidney of broiler chickens. Liv. Sci. 144, 269-274.

European Parliament, 2005. Regulation (EC) No 396/2005 of the European Parliament and of the Council of 23 February 2005 on Maximum Residue Levels of Pesticides in or on Food and Feed of Plant and Animal Origin And Amending Council Directive 91/414/EEC. Official J. European Union. 2005R0396- EN-26.10.2012-010.001

Frances, C., Hoizey, G., Lamiable, D., Millart, H. \& Trenque, T., 2003. Bromism from daily over intake of bromide salt. J. Toxicol. 41(2), 181-183.

Heeb, M.B., Criquet, J., Zimmermann-Steffens, S.G. \& Von Gunten, U., 2014. Oxidative treatment of bromide-containing waters: Formation of bromine and its reactions with inorganic and organic compounds - A critical review. Water Research 48, 15-42.

Hribar, B., Southall, N.T., Vlachy, V. \& Dill, K.A., 2002. How ions affect the structure of water. J. Am. Chem. Soc. 124, $12302-12311$.

Jain, A., Chaurasia, A., Sahasrabuddhey, B. \& Verma, K.K., 1996. Determination of bromide in complex matrices by precolumn derivatization linked to solid-phase extraction and high-performance liquid chromatography. J. Chromatogr. A 746(1), 31-41.

Jolles, Z.E., 1966. Br and its compounds. Academic Press. Toronto, Canada: 4-11, 487-497.

Korhonen, A., Hemminki, K. \& Vainio, H., 1982. Application of the chicken embryo in testing for embryotoxicity. Scand. J. Work Environ. Health. 8, 63-69.

Korsten, L., Casey, N.H.\& Chidamba, L., 2016. Evaluation of the risks associated with the use of rooftop rainwater harvesting and groundwater for domestic use and livestock watering. WRC 2175/2/16. Water Research Commission. Gezina, South Africa.

Loeber, J.G., Franken, M.A.M. \& van Leeuwen, F.X.R., 1983. Effect of sodium bromide on endocrine parameters in the rat as studied by immunochemistry and radioimmunoassay. Food Chem. Toxicol. 21(4), 391-404.

Lucht, H.L., Casey, N.H. \& Sawosz, E., 2018. Survival and development of embryos of Gallus gallus domesticus treated with inorganic bromide. S. Afr. J. Anim. Sci. 48(3), 583-589. 
Magazinovic, R.S., Nicholson, B.C., Mulcahy, D.E. \& David, D.E., 2004. Bromide levels in natural waters: its relationship to both levels of chloride and total dissolved solids and the implications for water treatment. Chemosphere 57, 329-335.

Mamabolo, M.C., Meyer, J.A. \& Casey, N.H., 2009. Effects of total dissolved solids on the accumulation of $\mathrm{Br}$, As and Pb from drinking water in tissues of selected organs in broilers. S. Afr. J. Anim. Sci. 39, 169-172.

Meyer, J.A., 1998. Modelling for the prediction of water quality guidelines for livestock in southern Africa. PhD thesis, University of Pretoria, South Africa.

Meyer, J.A., 2005. Project: Analyse borehole water for domestic use and livestock watering throughout the Republic of South Africa for a period of one year. Department of Agriculture Report No. 032005/02/26.

Meyer, J.A., 2015. Animal health assessment. In: J. M. Dabrowski (ed). An investigation of the contamination of water resources by agricultural chemicals and the impact on the environmental health: Volume 1: Risk Assessment of Agricultural Chemicals to Human and Animal Health. Chapters 5 and 8. WRC Report No. 1956/1/15. Water Research Commission. Gezina, South Africa.

Meyer, J.A \& Casey, N.H., 2004. Exposure assessment of potentially toxic trace elements in indigenous goats in rural communal production systems of the northern region of South Africa. S. Afr. J. Anim. Sci. 34, 219-222.

Meyer, J.A. \& Casey, N.H., 2012. Establishing risk assessment on water quality for livestock. Animal Frontiers 2(2), 4449.

Meyer, J.A., Casey, N.H. \& Coetzee, C.B., 1997. Water quality guidelines of for livestock watering in Southern Africa. Water SA 23(1), 7-12.

Ministry of Environment, British Columbia, 2015. Canada, British Columbia, Working Water Quality Guidelines. http://www.env.gov.bc.ca/wat/wq/wq_guidelines.html.

Moore, M.M. \& Chen, T., 2006. Mutagenicity of bromate: Implications for cancer risk assessment. Toxicology 221, 190196.

National Health and Medical Research Council and the Natural Resource Management Ministerial Council, Australian Government , 2016. National Water Quality Management Strategy 2011, version 3.2 updated February 2016. Australian Drinking Water Guidelines 6, version 3.2, 2016 . ISBN online: 1864965118.

NRC, 2005. Mineral tolerance of animals. 2nd ed. Revised. National Academy Press, Washington DC, USA.

Pavelka, S., 2004. Metabolism of bromide and its interference with the metabolism of iodine. Physiol. Res. 53, 81-90.

Pavelka, S., Babicky, A. \& Vobecky, M., 2005. Biological half-life of bromide in the rat depends primarily on the magnitude of sodium intake. Physiol. Res. 54, 649-654.

Pavelka, S., Babicky, A., Lener, J. \& Vobecky, M., 2002. Impact of high bromide intake in the rat dam on iodine transfer to the sucklings. Food Chem. Toxicol. 40, 1041-1045.

Pavelka, S., Babicky, A., Vobecky, M. \& Lener, J., 2000b. Bromide kinetics and distribution in the rat II. Bromide distribution in the body. Biol. Trace Elem. Res. 76, 67-74.

Pavelka, S., Babicky, A., Vobecky, M., Lener, J. \& Svandover, E., 2000a. Bromide kinetics and distribution in the rat I. Biokinetics of 82Br-Bromide. Biol. Trace Elem. Res. 76, 57-66.

Sawosz, E., Jaworski, S., Kutwin, M., Hotowy, A., Wierzbicki, M., Grodzik, M., Kurantowicz, N., Strojny, B., Lipińska, L. \& Chwalibog, A., 2014. Toxicity of pristine graphene in experiments in a chicken embryo model. Int. Jnl. Nanomed. 9, 3913-3922.

Water Research Commission (WRC), 2010. http://www.wrc.org.za/pages/Resources_Regionalstats.aspx (1)

World Health Organisation (WHO), 2011. Guidelines for drinking water quality. 4th ed. WHO Geneva, Switzerland. 